\title{
Environmental Impact Assessment and Environmental Audit in Large-Scale Public Infrastructure Construction: The Case of the Qinghai-Tibet Railway
}

\author{
Guizhen He $\cdot$ Lei Zhang $\cdot$ Yonglong Lu
}

Received: 19 May 2007/ Accepted: 24 June 2009/Published online: 28 July 2009

(C) Springer Science+Business Media, LLC 2009

\begin{abstract}
Large-scale public infrastructure projects have featured in China's modernization course since the early 1980s. During the early stages of China's rapid economic development, public attention focused on the economic and social impact of high-profile construction projects. In recent years, however, we have seen a shift in public concern toward the environmental and ecological effects of such projects, and today governments are required to provide valid environmental impact assessments prior to allowing large-scale construction. The official requirement for the monitoring of environmental conditions has led to an increased number of debates in recent years regarding the effectiveness of Environmental Impact Assessments (EIAs) and Governmental Environmental Audits (GEAs) as environmental safeguards in instances of large-scale construction. Although EIA and GEA are conducted by different institutions and have different goals and enforcement potential, these two practices can be closely related in terms of methodology. This article cites the construction of the Qinghai-Tibet Railway as an instance in which EIA and GEA offer complementary approaches to environmental impact management. This study concludes that the GEA approach can serve as an effective follow-up to the EIA and establishes that the EIA lays a base for conducting future
\end{abstract}

\section{G. He · Y. Lu (ه)}

State Key Laboratory of Urban and Regional Ecology, Research Centre for Eco-Environmental Sciences, Chinese Academy of Sciences, 18 Shuangqing Road, Beijing 100085, China e-mail: yllu@rcees.ac.cn

G. $\mathrm{He}$

e-mail: heguizh@yahoo.com.cn

\section{Zhang}

Environmental Policy Group, Wageningen University, Hollandseweg 1, 6706 Wageningen, The Netherlands
GEAs. The relationship that emerges through a study of the Railway's construction calls for more deliberate institutional arrangements and cooperation if the two practices are to be used in concert to optimal effect.

Keywords Environmental performance $\cdot$ Construction project · Large-scale construction program · Environmental audit · Environmental Impact Assessment · Qinghai-Tibet Railway

Since the early 1980s China's modernization course has featured numerous large-scale infrastructure construction projects and programs, including the Three Gorges Dam, the South-North Water Transfer, the Sloppy Land Conversion, and the Qinghai-Tibet Railway (China Internet Information Center 2008). As a whole such projects have succeeded in driving economic growth, especially during the last decade. To illustrate, Fig. 1 shows that the annual growth rates for fixed assets investments since 2003 remain above 25\%. In addition, according to The Tenth Five-Year Plan for National Economic and Social Development, for the years 2001-2005 more than 1100 large-scale public projects and programs were approved, with total investments amounting to 3000 billion RMB (about US\$380 billion) (National Development and Reform Commission 2001). These programs often consist of a group of projects and associated government policies, which collectively can have profound social, economic, and environmental effects. In this article we refer to such large-scale organized efforts as "governmental interventions." With public attention focused on the economic and social impacts of these governmental interventions in the early years of China's market revolution, they became extraordinarily potent symbols of national growth and renewal. Recent years, however, have seen rapidly 
Fig. 1 Total investment in fixed assets in China, 1980 2005 (Source: China Statistical Yearbook 2006)

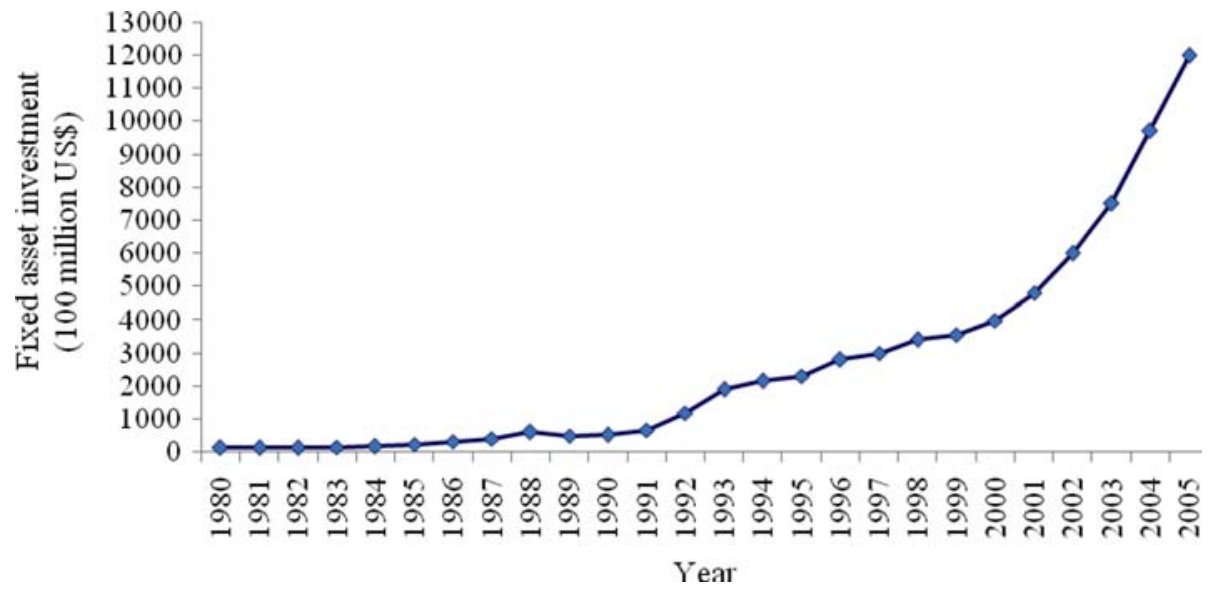

increasing attention and concern directed toward the environmental and ecological impacts of these massive projects. Water and soil erosion, biodiversity reduction, pollution, and other problems have all come under increasing scrutiny. Governments are now required to provide valid environmental impact assessments before permitting large-scale interventions of this kind.

In the international arena, the last three decades have seen the emergence and rapid development of legal avenues for lessening the environmental impact of large-scale construction. Of special interest to the study at hand are Environmental Impact Assessment (EIA), specifically Strategic Environmental Assessment (SEA) and Governmental Environmental Audit (GEA), both of which were first used in developed countries and are now extended to most parts of the world (Dalal-Clayton 2005; George and Kirkpatrick 2007; International Organization of Supreme Audit Institutions 2004; Sadler 1996; Sadler and Verheem 1996; van Leeuwen 2004). A GEA is an independent external audit of environmental conditions as codified by Supreme Audit Institutions (INTOSAI 2001). In response to mounting global environmental concerns, auditing institutions around the world have devoted increasing attention to environment-related governmental interventions since the early 1990s, and have expanded their focus from traditional financial audits to compliance and performance audits. In China, it is not by accident that a massive sandstorm in 2006, widely interpreted as a sign of dangerous environmental degradation in China's North, was followed by a socalled "environmental storm" and "audit storm." Debates concerning the implementation of EIA/SEA and GEA in China are concentrated less on their necessity and importance and more on the feasibility in terms of providing legitimate and comprehensive environmental assessments, given current institutional requirements and methodologies (He 2007; Ning and others 1988; Tao and others 2007; Wang and others 2003; Wu and Zhou 2000).
The comprehensive and effective environmental impact assessment of governmental interventions should include both ex ante evaluation and ex post evaluation. EIA provides for a kind of ex ante evaluation by certified bodies, the environmental assessment of proposed development programs and projects with the aim of informing decisionmaking (The Council of the European Union Directive 97/ 11/EC 1997; Environmental Impact Assessment Law of China 2002). Based on preventive and precautionary principles, major or even irreversible consequences of a given project can be avoided through a preliminary environmental impact assessment. Although a GEA, in theory, can be applied to different phases of project development (formulation, implementation, and modification/termination), in practice environmental audits often take place only after the project is begun. The same is true for current GEAs. A GEA is in fact a kind of ex post evaluation that aims to assess the extent to which policy goals are attained during or after construction plans are implemented, and in the process it can help to explain why certain policy goals have not been fully achieved. Although there are some difficulties in conducting effective GEAs in China, such as the lack of baseline and monitoring data, limited evaluation methods for determining the environmental impact of a plan/program/project, etc., GEAs offer a possible solution to the challenges facing EIA follow-up (but capacity building is required in strengthening GEAs and institutional linkages). GEAs and EIAs both evaluate the same subjects (governmental interventions), use similar methods or models, and aim to improve the performances of various interventions. Both GEAs and EIAs are practical operations and are conducted by professional organizations and accredited organizations (audit offices or EIA accredited bodies). In GEA or EIA reports, a systematic examination of the audited/assessed entity's environmental performances/ impacts are presented to authorities for enforcement, which in turn progresses according to the actual legal framework 
in which the GEA or EIA is conducted. This indicates that GEAs and EIAs can complement each other if the correct legislative and institutional arrangements are made.

Apart from remedial responsive measures, the worsening environmental situation demands that preventive and precautionary policymaking precede but do not overshadow the practice of proper environmental impact evaluation. EIA and GEA can be critical "checking points" for the effective environmental management of large-scale construction programs and projects. However, cooperation between bodies responsible for performing EIAs and GEAs on the same governmental intervention are still rare, and communications between the responsible parties are very limited. This study examines the case of Qinghai-Tibet Railway, focusing on points of mutual support or conflict within current legal and institutional frameworks governing EIA and GEA. This study also evaluates individual methods employed by the two practices, with an eye toward further sharing and cooperation.

Following this line of thinking, the following section (Analytical Framework) provides a theoretical framework adapted from the European Environmental Agency. Subsequently, the Qinghai-Tibet Railway Construction Project briefly introduces the project. Comparison between EIA and GEA reports our comparison between the EIA and the GEA under Analytical Framework by providing a checklist. The final section offers some conclusions.

\section{Analytical Framework}

Although the environmental evaluation model developed by the European Environmental Agency (EEA 2001) was developed originally for environmental policy evaluation, it provides a useful framework for evaluating various forms of governmental intervention. This model covers the whole process of governmental intervention, including the largescale construction programs and projects mentioned earlier. Figure 2 shows that environmental evaluation can focus on any of these phases of a given project for different purposes. Evaluation can therefore take place at any point during the project or program development process, which includes project formulation phase, the implementation phase and the modification/termination phase. An EIA in this case is meant to inform decision makers during the construction project and program formulation phase by foreseeing the possible environmental impacts presented by a range of possible scenarios (ex ante evaluation). A GEA, on the other hand, is conducted during or after the enforcement phase to evaluate negative and positive environmental effects/impacts (ex post evaluation). Although the importance of follow-up in the EIA process is clearly recognized, in practice it is often not conducted. This lack of follow-through has limited the impact of EIA (Ahammed and Nixon 2006; Arts 1998; Arts and others 2001; Au and others 1997; O'Faircheallaigh 2007; Morrison-Saunders and Arts 2008; Morrison-Saunders and others 2007; Shepherd 1998; UNEP 2002). We argue that a GEA can function very well as a follow-up for an EIA (but not to replace an EIA's own follow-up) in this case and that, in turn, an EIA can establish a baseline for a GEA.

Before comparing EIAs and GEAs systematically, we first define the scopes of EIAs and GEAs in this study. Currently, both practices are in continuous transition, and there are no single definitions agreed on. In short, EIA refers to environmental assessments at various levels. An EIA above project level, or an EIA of a program, plan or policy, is called an SEA (Sadler and Verheem 1996). It should be noted that program, plan, and policy are relative terms that can carry different meanings in different countries (Wood 1991; Oxford Brookes University 2004). The EIAs for major large-scale construction projects and programs in this study differ from project EIAs at the company level. These large construction programs and projects involve huge public budgets and are implemented by governmental departments. The scope of EIAs for these large projects includes assessments of compliance, environmental impact, effectiveness, and their alternatives.

While initially developed to perform economic and financial reviews, most government audit programs started to include environmental priorities in the 1990s. In 1995, environmental auditing and sustainable development became the leading theme of the 15th conference of the International Organization of Supreme Audit Institutions
Fig. 2 EIA and GEA in governmental intervention process (Adapted from EEA 2001)

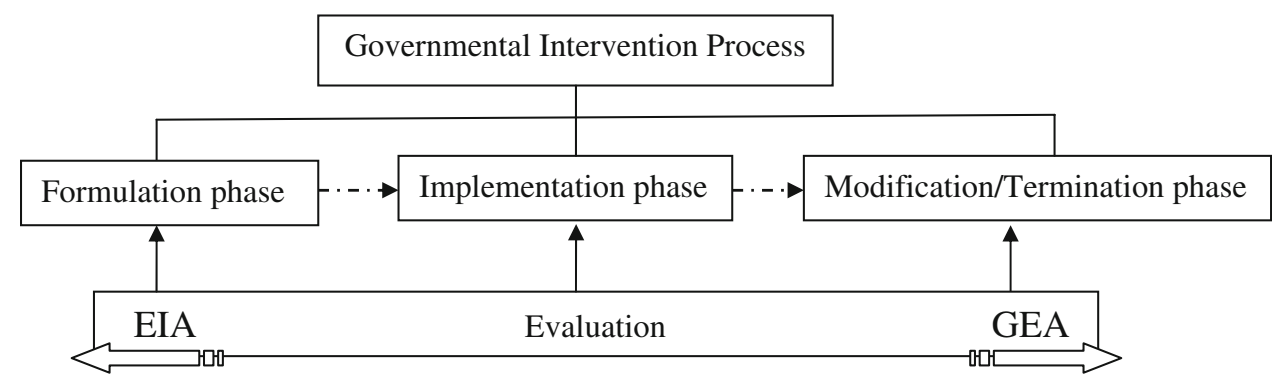


(INTOSAI). Subsequently a series of principles was developed as a base for environmental audit guidelines (INTOSAI 2001). Since then, audit institutions in different countries have actively embraced environmental auditing. Environmental audits are to be found in many different forms, at different levels of aggregation, and carried out by different actors. In this study, GEA refers to an environmental audit by public audit institutions on public activities, projects, and programs. The definition of follow-up under the Chinese EIA Law (provision 2.15) requires the verification of the accuracy of the environmental assessment and the determination of the effectiveness of measures taken to mitigate the adverse environmental effects of a plan and program after implementation. The assessment results should be reported to approving bodies. That EIA follow-up has rarely been practiced is partly due to a lack of motivation on the part of assessed organizations and partly due to a lack of supervision during and after the construction period (Briffett 1999; Lee and George 2000; Ning and others 1988; Wang and others 2003). This fact increases the importance and urgency of GEA practice in areas usually served only by EIA. At the very least, largescale construction programs and projects, already served by EIA, should also be considered for GEA immediately.

To conclude, EIA and GEA, as defined in this study, target the same subjects: governmental organizations and interventions. To understand to what extent the current EIA and GEA systems are complementary to each other and to identify barriers to effective cooperation, we proposed a list of standards, or a checklist, by which to establish systematic comparison: (1) legal status and institutional setup; (2) subjects, objectives, and contents; (3) procedures and methods; and (4) enforcement of results.

\section{The Qinghai-Tibet Railway Construction Project}

To improve the accessibility of Tibet and to reduce the developmental gap between the West and the East of China, the Qinghai-Tibet (Qing Zang) Railway was listed as a key national railway project in 2001. Construction began the same year (The State Council 2001). The railway's construction involved an investment of 33 billion RMB (US $\$ 4.2$ billion) from the central government and was completed in October 2005. The railway has been in operation since July 2006.

The area affected by this construction is considered the 'river source' and 'ecologic origin' of China and South Asia. The environmental impact of this linear infrastructure construction is generally characterized by a series of common effects, including water, waste and air pollution, traffic noise, modification of the landscape, direct habitat loss, habitat fragmentation, and biodiversity reduction in the impacted areas (Bohemen 1998; Byron 1999; Fernandes 2000; Forman and Alexander 1998; Gallardo and Sánchez 2004; Geneletti 2003; Treweek and others 1993). The QinghaiTibet railway is special for the difficulties encountered in its construction, for its high altitude, and for the short- and longterm environmental effects on the local area (Peng and others 2007; Sun 2005; Zhang 2002). The railway is $1142 \mathrm{~km}$ long, of which about $960 \mathrm{~km}$ has an elevation of $>4000 \mathrm{~m}$, and of which $550 \mathrm{~km}$ crosses permafrost with rare species habitats ("forbidden areas of living" and "unpopulated areas"). The highest point, Tanggulashan, reaches $5072 \mathrm{~m}$, which makes the railway the highest and the longest plateau railway on earth. The line passes through $55 \mathrm{~km}$ of wetlands covering horizontal and vertical alpine landscapes, the wildlife habitats of Kekexili, and the three-river source region (Fig. 3). Altogether the railway runs across about $506 \mathrm{~km}$ of five existing and six planned nature reserves. It also goes through five water systems. Since the beginning of the construction of the Qinghai-Tibet Railway, experts were unanimous that "given the year-round permafrost, extreme cold and deficient oxygen, and the fragile ecological environment along the line, developing necessary preventive measures would lessen the environmental risks of the railway pre-, in-, and post-construction" (Chen and others 2003; Sun 2005, 2006). Thus, an EIA was conducted by the First Railway Survey and Design Institute (FRSDI) under the Ministry of Railway (Ministry of Transport in March, 2008) and a report was produced in 2001 (FRSDI 2001a; SEPA 2003). At the end of the construction, China National Audit Office (CNAO) conducted an environmental audit on the project in 2005. This case provides a perfect opportunity to observe how EIA and GEA work in the same project. In the following paragraphs, we use the checklist presented above to compare EIA and GEA practices and to analyze their relationships.

\section{Comparison Between EIA and GEA}

\section{Legal Status and Institutional Setup}

As mentioned above, according to China's EIA Law (2002), environmental assessment includes the assessment of plans, programs, and projects. Such assessment should be conducted by bodies that are accredited by the Ministry of Environmental Protection (MEP) (State Environmental Protection Administration; SEPA) before March 2008. It is the responsibility of the executive organizations to request an accredited body to conduct an environmental impact assessment. These accredited professional assessment bodies mainly exist in universities or research institutes, with different capacities for projects of different scales. Professional assessors must hold certificates issued by MEP based on examinations. The cost of conducting an 
Fig. 3 Photos of the project sites for the Qinghai-Tibet Railway
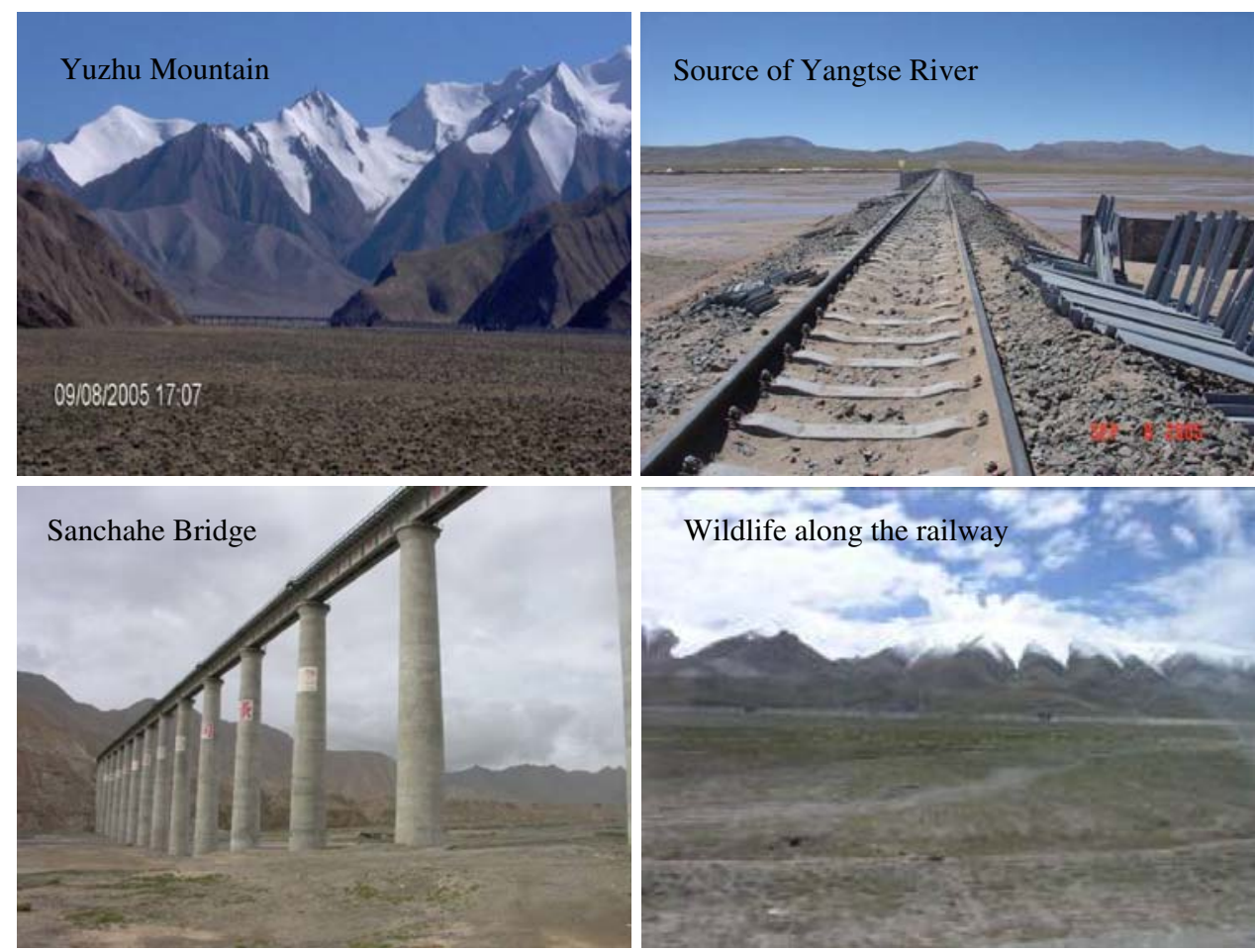

EIA is paid by the assessed organizations. In the case of the Qinghai-Tibet Railway Project, the Qinghai-Tibet Construction Company invited the First Railway Survey and Design Institute under the Ministry of Railway to conduct the EIA in 2001. A report was produced and approved by MEP in the same year. No independent assessment by a third party is required.

Audit institutions did not exist in China until December 1982, when the National People's Congress (NPC) adopted a resolution to establish an audit system in China. The necessity for an independent audit office was acknowledged in the amended Constitution that same year. Following this resolution and the Constitution, the National Audit Office was established in September 1983. Accordingly, provincial, municipal and county governments set up local audit institutions. In August 1994, the first Audit Law of the People's Republic of China was formally promulgated to strengthen state supervision through audit practices, to promote the development of clean government, and to ensure the healthy development of the national economy. The Audit Law defines the basic principles for government audit supervision, government audit institutions and auditors, the responsibilities and powers of audit institutions, audit procedures, and the legal liability of auditors. This situation differs from that in some Western countries, where audit institutions are independent of their government and report to the parliament (such as is the case in The Netherlands, Canada, and the United States), CNAO is under the administration of the State Council, and its local counterpart audit institutions report to both the local governments and the upper level audit institutions. Audits of large government-financed construction programs and projects have long been a subject for the audit institutions, but mainly focus on financial issues and conformity with the project specifications and rarely on the performance. During the 1998 institutional restructuring within the Chinese government, for the first time the State Council explicitly bestowed the function of environmental auditor on audit institutions by approving the CNAO's restructuring proposal. Correspondingly, the CNAO set up a department specialized in environmental audit, i.e., the Agricultural Resources and Environmental Audit Department. Its scope of environmental audit includes environmental protection budgets, the environmental impacts of industrial, farming, and forestry activities, and other areas related to sustainable development. Functional departments in charge of environmental audit are established within audit institutions at various levels. As a result, CNAO has helped to increase the sense of environmental protection and environmental legislation among the general public. Since 2000, the environmental audit has been added to relevant audit regulations, such as audits of large construction projects. As required and specified in the Standard of Audit Institutions on State Construction Projects Audit (National Audit Office of People's Republic of China 2003, Article 21, 22), the enforcement and effectiveness of "synchronization of three operations" (simultaneous design, construction, and operation of environmental facilities with the main construction 
work) are to be checked in such an environmental audit. The cost of these environmental audits is covered by CNAO budget, and thus audits are more independent from the auditees. In cases where an environmental audit is based on an EIA report, a GEA actually functions partly as a third-party examination of the corresponding EIA. Professional auditors also need hold CNAO certificates awarded via an examination system.

Given the huge ecological impact of the Qinghai-Tibet Railway project, CNAO listed it on the annual audit plan in 2005. Under the leadership of CNAO, about 50 auditors from 12 regional resident audit offices and provincial audit bureaus were organized to conduct an environmental audit of the intervention that same year. The audit report was published and was accessible by the public via the internet in 2006 (National Audit Office of People's Republic of China 2006).

To conclude, the current laws governing the EIA and GEA have provided the precedent for conducting environmental assessments and environmental audits on government-financed construction programs and projects. Professional institutions have been established for providing assessment and audit services according to corresponding laws and regulations. In theory, the results of the EIA should support decision making, but in the case of the Qinghai-Tibet Railway, an EIA's aim is to identify the environmental impact and to propose mitigation measures during a project's construction. The EIA here did not affect the approval of the project by the China's State Development and Reform Commission (SDRC). Comparatively, the GEA's timely intervention at the end of construction provided an independent check and verification of results mainly based on the EIA report. Unfortunately, in this case, the conclusions reached in the audit report were not communicated with EIA team or MEP.

\section{Subjects, Objectives, and Contents}

Both EIAs and GEAs target the government-financed programs and projects. The aim of an EIA is to predict and to assess the possible environmental impacts of different scenarios to better inform decision-making. A GEA checks and verifies the effectiveness of proposed mitigation measures and management plans (Dipper and others 1998; Liu and others 2002; Wood and others 2000). Thus, in terms of content, there are many similarities between EIA and GEA. These similarities lie in the two systems' treatment of environmental impact, effectiveness, performance, and compliance.

The EIA of the Qinghai-Tibet Railway project focused on its environmental impacts, the effectiveness of different options, and compliance with existing regulations. In addition, in accordance with the nature of the project, the
Ministry of Water Resources conducted the Water and Soil Conservation Plan (WSCP) (FRSDI 2001b) upon the request of the construction organization (NPC 2002; the State Council 1998), which focused more on the conservation measures. In the EIA report and the WSCP report on the Qinghai-Tibet Railway, major possible environmental effects were identified on alpine vegetation, wildlife resources and nature reserves, wetlands, permafrost and natural landscape, water and soil conservation, and water, air, and solid waste pollution. During the construction, management and engineering countermeasures were taken to prevent adverse environmental effects that had been predicted in the EIA report and WSCP report.

Four years later, when the CNAO came to audit the ecological and environmental effects, performance, and regulatory compliance of the construction project, they took the EIA report and the WSCP as the starting point. The CNAO audit team focused on six types of problem in the railway's construction: (1) vegetation and water and soil conservation; (2) wildlife and biodiversity preservation; (3) permafrost conservation; (4) wetlands preservation; (5) protection of water sources and prevention of water and waste pollution; and (6) environmental supervision and education (Table 1). Therefore, the EIA report and WSCP, along with the required monitoring and supervision conducted during the construction phase, have provided important baseline data for environmental auditing. It is assumed that better communication and coordination between EIA and GEA in this case could have increased the availability of accurate data for audit, though perhaps not solved the problem entirely. In addition, the EIA and GEA in this case both focused mainly on predictable impacts and engineering measures. Possible measures not related to engineering, such as the implementation of projects meant to raise the ecological awareness of local communities and to establish self-sustained local management capacity and mechanisms, are not properly addressed in this case.

\section{Procedures and Methods}

In general, EIAs and GEAs follow similar procedures including preparation phase, implementation phase, report phase, and follow-up. As presented in Table 2, they differ in the detailed contents of each step.

From these comparisons, it is clear that many of the steps in required by an EIA correspond to those required by a GEA in obtaining information on a certain aspect of the project, but that these steps occur, respectively, at different stages. This requires different data collection methods and analysis methods on the part of the two systems. Table 3 lists the most commonly applied methods for evaluating interventions, such as this construction project. Each 
Table 1 Environmental auditing conclusions on the major environmental impacts and mitigation measures of Qinghai-Tibet Railway construction

\begin{tabular}{|c|c|c|}
\hline Impacts on & Mitigation measure of EIA & Audit conclusion of GEA \\
\hline $\begin{array}{l}\text { Alpine vegetation and water } \\
\& \text { soil conservation }\end{array}$ & $\begin{array}{l}\text { 1. Appropriate construction plan } \\
\text { 2. Engineering measures for protecting } \\
\text { vegetation and defending against erosion } \\
\text { 3. Turf planting and surface vegetation } \\
\text { restoration }\end{array}$ & $\begin{array}{l}\text { 1. More than } 96 \% \text { of facilities met the requirements } \\
\text { 2. All engineering facilities finished as planned } \\
\text { 3. Control rate of discarded materials was } 100 \% \\
\text { 4. Degree of soil erosion was slight }\end{array}$ \\
\hline $\begin{array}{l}\text { Nature reserves and } \\
\text { endangered wildlife }\end{array}$ & $\begin{array}{l}\text { 1. Optimizing line } \\
\text { 2. Constructing special channels for wild } \\
\text { animals } \\
\text { 3. Work time management }\end{array}$ & $\begin{array}{l}\text { 1. Thirty-three channels were built } \\
\text { 2. The technical requirements of EIA report were achieved } \\
\text { for four surveyed channels }\end{array}$ \\
\hline Permafrost protection & $\begin{array}{l}\text { 1. Careful construction plan } \\
\text { 2. Substituting facilities for railway } \\
\text { 3. Proactively cooling down the roadbed }\end{array}$ & $\begin{array}{l}\text { 1. All protection facilities were finished as planned in EIA } \\
\text { report } \\
\text { 2. Effectiveness of relevant measures was positive }\end{array}$ \\
\hline Alpine lakes and wetlands & $\begin{array}{l}\text { 1. Substituting viaducts for railway } \\
\text { 2. Increasing roadbed stability }\end{array}$ & 1. All facilities were finished as planned in EIA report \\
\hline $\begin{array}{l}\text { Water, air, and solid waste } \\
\text { pollution prevention } \\
\text { and control }\end{array}$ & $\begin{array}{l}\text { 1. Preventing water pollution by engineering } \\
\text { methods } \\
\text { 2. Reducing wastewater } \\
\text { 3. Decreasing the dust } \\
\text { 4. Appropriately treating solid waste }\end{array}$ & $\begin{array}{l}\text { 1. By and large, the principle of "centralized collection, } \\
\text { transportation and disposal" was applied } \\
\text { 2. The water quality of local rivers and lakes showed no } \\
\text { obvious change }\end{array}$ \\
\hline $\begin{array}{l}\text { Environmental management, } \\
\text { supervision, and education }\end{array}$ & $\begin{array}{l}\text { 1. Establishing EMS and supervision system } \\
\text { 2. Strengthening training }\end{array}$ & $\begin{array}{l}\text { 1. Environmental supervision was conducted on time and } \\
\text { effectively } \\
\text { 2. Managers and staff attended the training }\end{array}$ \\
\hline
\end{tabular}

Note: The CNAO (2006) focused more on the financial. In this article, we mainly pay attention to environmental impacts of the Qinghai-Tibet Railway

Table 2 Comparison between EIA and GEA procedures

\begin{tabular}{|c|c|c|}
\hline Procedure & EIA & GEA \\
\hline Phase I: Preparation & $\begin{array}{l}\text { - Analyze the related laws and documents } \\
\text { - Describe environmental baseline } \\
\text { - Screen the assessment factors } \\
\text { - Define the scope of assessment } \\
\text { - Identify targets and indicators } \\
\text { - Make the assessment outline }\end{array}$ & $\begin{array}{l}\text { - Select and prioritize the potential audit topics } \\
\text { - Preliminary survey of the background situation } \\
\text { - Make field audit plan } \\
\text { - Inform the audited organizations }\end{array}$ \\
\hline $\begin{array}{l}\text { Phase II: } \\
\text { Implementation }\end{array}$ & $\begin{array}{l}\text { - Predict and evaluate impacts of alternatives } \\
\text { - Propose environmentally preferred alternatives } \\
\text { - Mitigate and enhance impact of chosen } \\
\text { alternatives } \\
\text { - Develop public participation, monitoring, and } \\
\text { follow-up plan }\end{array}$ & $\begin{array}{l}\text { - Define audit criteria } \\
\text { - Collect audit evidence } \\
\text { - Attain audit findings } \\
\text { - Determine the causes and effects of the findings } \\
\text { - Develop audit recommendations } \\
\text { - Estimate likely impacts of the recommendations }\end{array}$ \\
\hline $\begin{array}{l}\text { Phase III: Report } \\
\text { production }\end{array}$ & $\begin{array}{l}\text { - Analyze the data } \\
\text { - Provide the assessment results and conclusions } \\
\text { - Complete the final report } \\
\text { - Self-evaluation }\end{array}$ & $\begin{array}{l}\text { - Draft the audit report } \\
\text { - Ask for opinions } \\
\text { - Finalize and publish the audit report } \\
\text { - Self-evaluation }\end{array}$ \\
\hline Phase IV: Follow-up & $\begin{array}{l}\text { - Conduct the environmental impacts monitoring } \\
\text { - Provide feedback to the assessment bodies }\end{array}$ & $\begin{array}{l}\text { - Check the enforcement } \\
\text { - Provide feedback to the audit institutions, the legislatures and } \\
\text { the governments }\end{array}$ \\
\hline
\end{tabular}


method or tool has its own characteristics, and its effective application depends on the actual situation and conditions.

In the case of the Qinghai-Tibet Railway project, some of the methods were adopted at different steps of the EIA and the GEA, respectively (Table 4). For instance, the Delphi method was used in the EIA to identify the major environmental impacts of the project (FRSDI 2001a, 2001b). Existing monitoring information and documents were used to describe the impacts. Where the data and information were not existent, additional on-site observations and GIS were done to generate data regarding vegetation distribution, population and movement of antelopes

Table 3 The most commonly applied methods for evaluating interventions

\begin{tabular}{|c|c|c|c|c|c|c|}
\hline \multirow[t]{2}{*}{ Method } & \multicolumn{3}{|l|}{ EIA } & \multicolumn{3}{|l|}{ GEA } \\
\hline & Phase I & Phase II & Phase III & Phase I & Phase II & Phase III \\
\hline Literature and documentary review & $\checkmark$ & & & $\boldsymbol{v}$ & $\boldsymbol{v}$ & \\
\hline Field survey & $\boldsymbol{v}$ & $\checkmark$ & & $\boldsymbol{v}$ & $\boldsymbol{v}$ & \\
\hline Interview & $\boldsymbol{v}$ & $\checkmark$ & & $\boldsymbol{v}$ & $\boldsymbol{v}$ & \\
\hline Questionnaire & & $\boldsymbol{v}$ & & & $\boldsymbol{v}$ & \\
\hline Delphi method & & $\checkmark$ & & $\checkmark$ & $\checkmark$ & \\
\hline Impacts matrices & $\checkmark$ & & & & & \\
\hline Checklists & & $\boldsymbol{v}$ & & & $\checkmark$ & \\
\hline Workshop & & $\boldsymbol{v}$ & $\boldsymbol{v}$ & $\boldsymbol{v}$ & $\boldsymbol{v}$ & $\boldsymbol{v}$ \\
\hline Network method & $\boldsymbol{v}$ & & & & $\boldsymbol{v}$ & \\
\hline GIS & $\checkmark$ & & & & & \\
\hline CBA & & $\boldsymbol{v}$ & & & $\boldsymbol{v}$ & \\
\hline Material flow analysis & $\checkmark$ & & & & & \\
\hline Multicriterion analysis & & & & & $\boldsymbol{v}$ & \\
\hline Analogy analysis method & $\boldsymbol{v}$ & $\checkmark$ & & & $\boldsymbol{v}$ & \\
\hline Scenario analysis & & $\checkmark$ & & & & \\
\hline Before and after comparison & & $\checkmark$ & & & $v$ & \\
\hline Mathematical model & & $\checkmark$ & & & $\checkmark$ & \\
\hline Physical model & & $\checkmark$ & & & & \\
\hline Professional judgment approach & & $\checkmark$ & & $\boldsymbol{\nu}$ & $\boldsymbol{\nu}$ & \\
\hline
\end{tabular}

Table 4 Methods adopted by EIA and GEA for Qinghai-Tibet Railway project

\begin{tabular}{|c|c|c|c|c|c|c|}
\hline \multirow[t]{2}{*}{ Method } & \multicolumn{3}{|l|}{ EIA } & \multicolumn{3}{|l|}{ GEA } \\
\hline & Phase I & Phase II & Phase III & Phase I & Phase II & Phase III \\
\hline Literature and documentary review & $\boldsymbol{v}$ & & & $\boldsymbol{v}$ & $\boldsymbol{v}$ & \\
\hline Field survey & $\boldsymbol{v}$ & $\boldsymbol{v}$ & & $\checkmark$ & $\checkmark$ & \\
\hline Interview & $\boldsymbol{v}$ & $\checkmark$ & & $\boldsymbol{v}$ & $\boldsymbol{v}$ & \\
\hline Questionnaire & & $\boldsymbol{v}$ & & & $\boldsymbol{v}$ & $\boldsymbol{v}$ \\
\hline Delphi method & & $\checkmark$ & & $\checkmark$ & $\checkmark$ & \\
\hline Impacts matrices & $\boldsymbol{v}$ & & & & & \\
\hline Checklists & & $\boldsymbol{v}$ & & & $\checkmark$ & \\
\hline Workshop & & $\boldsymbol{v}$ & $\boldsymbol{v}$ & $\boldsymbol{v}$ & $\boldsymbol{v}$ & $\boldsymbol{v}$ \\
\hline GIS & $\checkmark$ & & & & & \\
\hline CBA & & $\boldsymbol{v}$ & & & & \\
\hline Environmental databases & & $\checkmark$ & & & $\boldsymbol{v}$ & \\
\hline Image interpretation & & $\checkmark$ & & $\boldsymbol{V}$ & $\checkmark$ & \\
\hline Scenario analysis & & $\checkmark$ & & & & \\
\hline Before and after comparison & & & & & $\checkmark$ & \\
\hline Mathematical model & & $\checkmark$ & & & & \\
\hline Professional judgment approach & & $\boldsymbol{v}$ & & $\boldsymbol{v}$ & $\boldsymbol{v}$ & $\boldsymbol{v}$ \\
\hline
\end{tabular}


along the planned railway. When it came to GEA, the method was used again to prioritize the most important environmental and ecological impacts ( 6 among the 15 from the EIA report) by giving different weights to different impacts. This has saved the auditors resources and time with which to identify priorities.

To conclude, the current procedures of EIA and GEA have similar steps involving different contents in each step. The choice of methods and techniques in each step depends on the actual situation and conditions and it should be both scientific and feasible.

\section{Enforcement of Results}

In theory, conclusions reached by an EIA should be used to decide whether or not a construction project can proceed. An EIA is given veto power according to Article 25, Article 31, and Article 32 of Chinese EIA Law. Where a project's EIA report is not examined, or is examined but not approved, the project shall not be allowed to start. If a construction unit does not do as is required by the provisions of this law, it may be fined and given administrative sanctions. In 2007 alone, we saw that 12 construction projects in nine Chinese provinces were suspended or not allowed to start because of an absent or incomplete of EIA report (Notices of Administrative Office, MEP 2007). However, it is often conducted both as a requirement for approval and as a means of avoiding excessive environmental impact. This is exactly what happened in the case of Qinghai-Tibet Railway project. The GEA of this project found that most of the proposed prevention and mitigation measures in the EIA report had been implemented during the construction, and some predicted ecological and environmental effects can now be observed. Long-term effects, such as the recovery of damaged vegetation and the effects on the migration of wild lives, cannot yet be observed. The conclusions of the GEA confirm that the railway is an "ecorailway" as a result of the implementation of the measures proposed in EIA. The GEA also confirms the effectiveness of EIA on this project.

\section{Conclusions}

The case of Qinghai-Tibet Railway Project has demonstrated that an EIA and a GEA can complement each other and that their effectiveness can be enhanced greatly if they are conducted on the same program or project. We can additionally conclude that a GEA has to be conducted especially in cases where EIA follow-up is weak (e.g., monitoring is lacking). This case also shows that most evaluation methods are fulfilled by both EIAs and GEAs as far as conditions allow. The EIA and GEA on this project were carried out separately, without conscious coordination and communication. In the future more deliberate institutional arrangements could help more coordinated EIAs and GEAs to overcome, to a certain extent, the existing limitations faced by environmental impact assessment in China. Such limitations include the lack of follow-up and enforcement of EIA conclusions and the lack of environmental baseline and monitoring data for conducting a GEA. However, the current legal and institutional frameworks for EIA and GEA are not designed to enable and facilitate this kind of cooperation. More communications between these two systems are needed to overcome departmental interests and limitations. Although the potential of EIA-GEA cooperation has not been fully explored in this case, this example illustrates how better environmental management and supervision on large construction works can be achieved through the tandem involvement of both systems. The Qinghai-Tibet Railway is therefore a good lesson and a model for other programs and projects in China, and perhaps elsewhere.

Acknowledgments This study was funded by the National Basic Research Program of China (2007CB407307), the international project between the Netherlands Royal Academy of Arts and Sciences and the Chinese Academy of Sciences (No. 08CDP005), and the Pilot Project of Knowledge Innovation Program of the Chinese Academy of Sciences (KZCX2-YW-420-5). The contents of this article represent the opinions of the authors, not necessarily those of the National Audit Office of China. The authors thank all interviewers and respondents of this study and the anonymous reviewers for their thoughtful comments on this article.

\section{References}

Ahammed AKMR, Nixon BM (2006) Environmental impact monitoring in the EIA process of South Australia. Environmental Impact Assessment Review 26(5):426-447

Arts J (1998) EIA follow-up-on the role of ex-post evaluation in Environmental Impact Assessment. GeoPress, Groningen, Netherlands

Arts J, Caldwell P, Morrison-Saunders A (2001) Environmental impact assessment follow-up: good practice and future directions-findings from a workshop at the IAIA 2000 Conference. Impact Assessment Project Appraisal, vol 19, issue 3, pp 175-185

Au EWK, Sanvicens GDE (1997) EIA follow up and monitoring. Report of the EIA process strengthening workshop, Canberra, Environmental Protection Agency, Australia, pp 91-107

Bohemen HD (1998) Habitat fragmentation, infrastructure and ecological engineering. Ecological Engineering 11(1-4):199-207

Briffett C (1999) Environmental impact assessment in East Asia. In: Petts J (ed) Handbook of environmental impact assessment, vol 1. Blackwell, Oxford, pp 143-167

Byron HJ (1999) Biodiversity issues in road environmental impact assessments: guidance and case studies. In: Evink GL, Garrett P, Zeigler D (eds) Proceedings of the third international conference on wildlife ecology and transportation. Department of Transportation, Tallahassee, FL, pp 211-220 
Chen H, Li SC, Zhang YL (2003) Impact of road construction on vegetation alongside Qinghai-Xizang highway and railway. Chinese Geographical Science 13(4):340-346

China Internet Information Center (2008) The large-scale programs of China. Available at: http://www.china.com.cn/chinese/zhuanti/ gjzdgc/963088.htm. Accessed 30 December 2008

China Statistical Yearbook (2006) China Statistics Press, Beijing, China

Dalal-Clayton B, Sadler B (2005) Strategic environmental assessment: a sourcebook and reference guide to international experience. London, Earthscan

Dipper B, Jones C, Wood C (1998) Monitoring and post-auditing in environmental impact assessment: a review. Journal of Environmental Planning and Management 41(6):731-747

European Environmental Agency (2001) Reporting on environmental measures: are we being effective? Environmental issue report No. 25

Fernandes JP (2000) Landscape ecology and conservation management - evaluation of alternatives in a highway EIA process. Environmental Impact Assessment Review 20(6):665-680

Forman RTT, Alexander LE (1998) Roads and their major ecological effects. Annual Review of Ecology and Systematics 29:207-231

Gallardo ALCF, Sánchez LE (2004) Follow-up of a road building scheme in a fragile environment. Environmental Impact Assessment Review 24:47-58

Geneletti D (2003) Biodiversity impact assessment of roads: an approach based on ecosystem rarity. Environmental Impact Assessment Review 23(3):343-365

George C, Kirkpatrick C (eds) (2007) Impact assessment and sustainable development: European practice and experience. Edward Elgar, Cheltenham, UK

He GZ (2007) Theory and methodology of environmental performance auditing. PhD dissertation. Chinese Academy of Sciences, Beijing (in Chinese)

International Organization of Supreme Audit Institutions (2001) Guidance standards and guidelines on environmental auditing. INTOSAI, The Hague, Netherlands

International Organization of Supreme Audit Institutions (2004) Working Group on Environmental Auditing. Results of the third survey on environmental auditing (2003). INTOSAI Working Group on Environmental Auditing, Canada

Lee N, George C (eds) (2000) Environmental assessment in developing and transitional countries. Wiley and Sons, Chichester, UK

Liu DZ, Wang BQ, Chen JX (2002) Current status, development trends and audit techniques of government environmental auditing. Audit Research 6:17-23 (in Chinese)

Morrison-Saunders A, Arts J (eds) (2008) Assessing impact: handbook Of EIA and SEA follow-up. Earthscan, London

Morrison-Saunders A, Marshall R, Arts J (2007) EIA follow-up international best practice principles. Special Publication Series No. 6. International Association for Impact Assessment, Fargo, ND

National Audit Office of People's Republic of China (2003) Standard of audit institutions on state construction projects audit. Promulgated January 23

National Audit Office of People's Republic of China (2006) Audit report no. 2 of 2006 (General Series No. 14): Audit and investigation findings on the use of funds for environmental protection of the Qinghai-Tibet Railway. Available at: http://www.cnao.gov.cn/ main/articleshow_ArtID_921.htm. Accessed 5 June 2009

National Development and Reform Commission of People's Republic of China (2001) The Tenth five-year plan for national economic and social development, Beijing

National People's Congress of People's Republic of China (2002) Environmental Impact Assessment Law of the People's Republic of China. Adopted at the 30th Meeting of the Standing Committee of the Ninth National People's Congress on October
28, 2002; promulgated by Order No. 77 of the President of the People's Republic of China. English version provided by ACEE/ SEPA $(10 / 18 / 05)$

Ning D, Wang H, Whitney J (1988) Environmental impact assessment in China: present practice and future developments. Environmental Impact Assessment Review 8(1):85-95

Notices of Administrative Office, Ministry of Environmental Protection, China (2007) Available at: http://www.zhb.gov.cn/info/ gw/huanban/index_1.htm. Accessed 6 July 2008

O'Faircheallaigh C (2007) Environmental agreements, EIA follow-up and aboriginal participation in environmental management: the Canadian experience. Environmental Impact Assessment Review 27(4):319-342

Oxford Brookes University (2004) Web-based distance-learning training packages on SEA. Available at: http://www.brookes.ac.uk/ schools/planning/SEAmicro/ppp\%20defs.tml. Accessed 28 September 2004

Peng CH, Ouyang H, Gao Q (2007) Building a "green" railway in China. Science 316:546-547

Sadler B (1996) Environmental assessment in a changing world: evaluating practice to improve performance. International Study of the Effectiveness of Environmental Assessment. Final report No. EN106-37/1996E. Canadian Environmental Assessment Agency

Sadler B, Verheem R (1996) Strategic environmental assessment: status, challenges and future directions. The International study of effectiveness of environmental assessment. Ministry of Housing, Spatial Planning and the Environment, The Netherlands

Shepherd A (1998) Post-project impact assessment and monitoring. In: Porter AL, Fittipaldi JJ (eds) Environmental methods review: retooling impact assessment for the new century. Army Environmental Policy Institute, Atlanta, GA, pp 164-170

State Environmental Protection Administration (2003) Technical guidance for environmental impact assessment for plans and programs (interim). State Environmental Protection Administration, Beijing. English version, 11 August 2003. Available at: http:// www.sepa.gov.cn/info/gw/huangfa/200308/t20030801_86602.htm

Sun YF (2005) Build the first-class plateau railway in the world. Engineering Sciences 3(3):1-12

Sun SY (2006) The features of the ecological environment and protective solutions along the Qinghai-Tibet Railway. Protection Engineering Sciences 4(2):35-42 (in Chinese)

Tao T, Tan Z, He X (2007) Integrating environment into land-use planning through strategic environmental assessment in China: towards legal frameworks and operational procedures. Environmental Impact Assessment Review 27:243-265

The Council of the European Union (1997) Council Directive 97/11/ EC of 3 March 1997 amending Directive 85/337/EEC of 27 June 1985 on the assessment of the effects of certain public and private projects on the environment

The First Railway Survey and Design Institute (2001a) Environmental impact statement of Qinghai-Tibet Railway. Lanzhou City, Gansu Province

The First Railway Survey and Design Institute (2001b) Water and soil conservation plan of Qinghai-Tibet Railway. Lanzhou City, Gansu Province

The State Council of the People's Republic of China (1998) Regulations on the Administration of Construction Project Environmental Protection. Decree No. 253 of the State Council. November 29

The State Council of the People's Republic of China (2001) Official reply of the State Council on approving the construction of the QinghaiTibet Railway Program from Geermu to Lhasa. No. 72. June 27

Treweek JR, Thompson S, Veicht N, Japp C (1993) Ecological assessment of proposed road developments: a review of environmental statements. Journal of Environmental Planning and Management 36(3):295-307 
United Nations Environment Program (2002) Environmental Impact Assessment training resource manual. Topic 11: Implementation and follow up, 2nd edn. UN, Geneva, pp 403-430

Van Leeuwen S (2004) Developments in environmental auditing by supreme audit institutions. Environmental Management 2:163172

Wang Y, Morgan RK, Cashmore M (2003) Environmental impact assessment of projects in the People's Republic of China: new law, old problems. Environmental Impact Assessment Review 5(23):543-579
Wood C (1991) EIA of policies, plans and programs. EIA Newsletter $5: 2-3$

Wood CM, Dipper B, Jones C (2000) Auditing the assessments of the environmental impacts of planning projects. Journal of Environmental Planning and Management 43(1):23-47

Wu ZB, Zhou YL (2000) Procedures and problems for environmental audit in China. Chongqing Environmental Science 3(9-1):1-17

Zhang YQ (2002) Negative impact of Qinghai-Tibet Railway construction on ecological environment of Qinghai-Tibet Plateau. Bulletin of Soil and Water Conservation 22(4):50-53 (in Chinese) 